\title{
Operational Limitations of Arctic Waste Stabilization Ponds: Insights from Modeling Oxygen Dynamics and Carbon Removal
}

Ragush, Colin M.; Gentleman, Wendy C.; Hansen, Lisbeth Truelstrup; Jamieson, Rob C.

Published in:

Journal of Environmental Engineering

Link to article, DOI:

10.1061/(ASCE)EE.1943-7870.0001371

Publication date:

2018

Document Version

Peer reviewed version

Link back to DTU Orbit

Citation (APA):

Ragush, C. M., Gentleman, W. C., Hansen, L. T., \& Jamieson, R. C. (2018). Operational Limitations of Arctic Waste Stabilization Ponds: Insights from Modeling Oxygen Dynamics and Carbon Removal. Journal of Environmental Engineering, 144(6). https://doi.org/10.1061/(ASCE)EE.1943-7870.0001371

\section{General rights}

Copyright and moral rights for the publications made accessible in the public portal are retained by the authors and/or other copyright owners and it is a condition of accessing publications that users recognise and abide by the legal requirements associated with these rights.

- Users may download and print one copy of any publication from the public portal for the purpose of private study or research.

- You may not further distribute the material or use it for any profit-making activity or commercial gain

- You may freely distribute the URL identifying the publication in the public portal 


\section{Operational Limitations of Arctic Waste} Stabilization Ponds - Insights from Modelling Oxygen Dynamics and Carbon Removal

4 Colin M. Ragush, Postdoctoral Fellow

5 Centre for Water Resources Studies, Dalhousie University, 1360 Barrington Street, 6 Halifax, NS, Canada, B3H 4R2

7 Tel.: 1-902-229-9736; Fax: 1-902-494-3108; Email: Colin.Ragush@Dal.Ca

Wendy C. Gentleman, Associate Professor

9 Department of Engineering Mathematics and Internetworking, Dalhousie University, 269 Morris Street PO Box 15000, Halifax, Nova Scotia, Canada, B3H 4R2

Email: Wendy.Gentleman@Dal.Ca

Lisbeth Truelstrup-Hansen, Professor Department of Process Engineering and Applied Science, Dalhousie University, 1360 Barrington Street, Halifax, NS, Canada, B3H 4R2 Current address: National Food Institute, Technical University of Denmark, 2800 Kgs. Lyngby, Denmark Email: ltruelst@Dal.Ca and litr@food.dtu.dk

Rob C. Jamieson, Professor Civil and Resources Engineering Dept., Dalhousie University, 1360 Barrington Street, Halifax, Nova Scotia, Canada, B3H 4R2

Email: Jamiesrc@Dal.Ca

Presented here is a mechanistic model of the biological dynamics of the photic zone of a single-cell arctic Waste

Stabilization Pond (WSP) for the prediction of oxygen concentration and the removal of oxygen demanding substances. The model is an exploratory model to assess the limiting environmental factors affecting treatment 
photosynthetic oxygen production, that mainly contribute to creating differences in $\mathrm{CBOD}_{5}$ removal rates and the development of aerobic conditions. The model was also sensitive to atmospheric aeration rates at low temperature providing further evidence that low oxygen availability limits the treatment of $\mathrm{CBOD}_{5}$ in cold climate WSPs. During the development process, it was discovered that common formulations of depth-integrated phytoplankton growth performed poorly for our modeled system, which was a quiescent eutrophic environment. This paper presents a new phytoplankton growth formula within the paradigm of a poorly-mixed eutrophic system that may find utilization in other eutrophic, colored or turbid systems. The novel aspect of the approach is that the depth integrated phytoplankton growth function was formulated upon the premise that the phytoplankton population would be capable to orient themselves to optimize their growth under poorly mixed conditions, and the average growth rate of the phytoplankton population must decrease as crowding puts pressure on shared resources. The general agreement of the model with the experiments, combined with the simplicity of the depth integrated box model, suggests there is potential for further development of the model as a tool for assessing proposed arctic WSP designs. The sensitivity analysis highlighted the uncertainty and importance of the parameterization of bacterial and phytoplankton physiology and metabolism in WSP models.

\section{Introduction}

Waste Stabilization Ponds (WSPs) are, in essence, shallow highly eutrophic water bodies used for municipal wastewater treatment, and operate by allowing biological (microbial degradation) and physical treatment processes (settling) to reduce the $\mathrm{CBOD}_{5}$ (Carbonaceous Biochemical Oxygen Demand - Day 5) concentration prior to discharge from the treatment system. However, the design and operation of arctic WSPs is typically different than those used in warmer climates due to the prevailing cold temperatures, and short ice-free time periods. Arctic WSPs are operated as controlled discharge storage ponds; raw wastewater is continuously received into the WSP year round, but effluent is only discharged once per year, typically during late summer/early fall for a period of 2-3 weeks. The surfaces of the arctic WSPs stay frozen for 9-10 months and influent wastewater temperatures quickly approach $0{ }^{\circ} \mathrm{C}$ limiting the biological treatment capabilities of the system during this period. As a result, WSPs at the start of the summer treatment season, or ice free period, contain high concentrations of oxygen demanding substances $\left(\mathrm{CBOD}_{5}>200 \mathrm{mg} / \mathrm{l}\right)$. The level of $\mathrm{CBOD}_{5}$ treatment during the summer season is highly variable 
(Ragush et al. 2017), and the limitations and best operational practices of single-cell WSPs operating in arctic environments have not been deeply investigated.

The current design guidelines and "best practices" that are presently in use in the Arctic were developed from the

61 performance of systems operating in northern climates and expert experience (Dawson \& Grainge, 1969; Heinke et al., 1991). However, these design guidelines were meant to meet less stringent effluent regulations (Nunavut Water Board, 2015) than are currently being implemented across Canada (Government of Canada, 2012). Also, the systems used to develop the guidelines were generally i) located in cold temperate (such as northern interior United States or Canada) or sub-arctic climates and/or were ii) continuous flow systems (US EPA, 1983). Since most northern communities (e.g. 19 of 25 in Nunavut, Canada) depend on WSPs as a component of their municipal wastewater treatment, the applicability of such guidelines for the design of arctic WSPs warrants further scrutiny.

To better understand the climatic and operational factors influencing the performance of single cell WSPs in cold climates, Ragush et al. (2017) used a bench-scale factorial design experiment to examine the influences of temperature, irradiance, organic loading and initial carbon concentration conditions at the onset of summer. The

71 focus was to observe how the aforementioned parameters impact the development of an aerobic environment and $\mathrm{CBOD}_{5}$ treatment performance. In this experiment, mesocosms were constructed to represent Arctic WSPs operating for 40 days, which is roughly the length of the summer treatment season in many Nunavut, Canada communities.

74 Statistical analysis by Ragush et al. (2017) found that all four factors significantly impacted the oxygen state and $\mathrm{CBOD}_{5}$ removal rates.

Here, a mechanistic model is presented with the intent to represent the carbon and oxygen dynamics in arctic WSPs. This model is to be used to explore existing knowledge gaps and uncertainties with respect to the dynamics occurring in these systems and to determining limiting factors of system performance. Ultimately, the model can be developed into a tool to assess arctic WSP design and optimization. With the focus of this study being on the mechanisms of $\mathrm{CBOD}_{5}$ removal and oxygen concentration dynamics, the model needed to adequately represent the

81 length of time required for algae populations to reach levels necessary to produce an aerobic ( $>2 \mathrm{mg} / \mathrm{L}$ dissolved 82 oxygen) environment under arctic temperature and light conditions. One of the ultimate objectives of this work was to identify organic loading regimes for arctic WSPs that facilitate the formation of aerobic environments within the relatively short (approximately 40 - 60 days) summer treatment season. During the development of this model, it 
was found that formulations from the literature poorly represented phytoplankton growth in our stagnant eutrophic environment with high light attenuation. Thus, a mathematical representation for phytoplankton growth under these particular conditions was developed. Here, we present this new phytoplankton growth model, for environments that are eutrophic and have high light attenuation, which is likely to be applicable and have merit for simulations of other ecosystems where phytoplankton are space limited due to a small vertical window in optimal photic depth. Incorporating the new phytoplankton growth representation, we present a process-based model to predict dissolved oxygen and $\mathrm{CBOD}_{5}$ concentrations in WSPs and provide an assessment of the local sensitivity of associated parameters of such a model through a one-factor-at-a-time (OFAT) sensitivity analysis. A brief discussion of simulation results of the sensitivity analysis is provided in the context of WSP design. The formulation of the model, specifically the depth-integrated phytoplankton growth function, and the results of the sensitivity analysis are likely to be adaptable to other eutrophic systems.

\section{Model Development}

The use of process-based models to design and evaluate wastewater treatment processes, specifically activated sludge systems, is well established (Orhon \& Artan, 1994; Henze et al. 2000), and principles from these systems have also been coupled with ecosystem models and applied to WSPs (e.g. Gehring et al., 2010; Fritz et al., 1979; Buhr \& Miller, 1983; Moreno-Grau et al., 1996; Banks et al., 2003; Beran \& Kargi, 2005). These models display a large range in complexity and formulations depending upon the studies' objectives and design characteristics of the system. We reviewed the literature, assessing models for their applicability to our system and our focus on the prediction of dissolved oxygen concentration and $\mathrm{CBOD}_{5}$ removal in WSPs operating in arctic environments. Banks et al. (2003), an adaptation of Buhr \& Miller (1983), presented a box model of the photic zone (i.e. vertical surface region where there is sufficient light for photosynthesis) that forms the cornerstone of the model presented in this paper. However, when Banks et al.'s formulation was applied to the bench-scale system presented in Ragush et al. (2017) we found that it was unable to adequately predict the oxygen state and $\mathrm{CBOD}_{5}$ concentration. The concentrations of oxygen, timing of when oxygen rose, and $\mathrm{CBOD}_{5}$ removal could not be calibrated/validated between the entire set of experiments. The poor agreement is believed to be due to the fact that the Buhr \& Miller (1983) system was a high-rate algal pond, which is shallow and has a paddle system engineered to create continually 
111 well-mixed conditions. This is inconsistent with single cell WSPs operating in the Arctic that have greater depth and

112 limited mixing. Thus, we made several modifications to the Buhr \& Miller (1983) model.

\subsection{Model overview}

114 Figure 1 provides a schematic of the model along with references to the equations in Table 1 that were used to

115 represent the major processes. It is stressed to the reader that the model is a heuristic representation of arctic WSPs, and accordingly is an abstraction of reality. This investigation uses the model to assess: i) the parameters that have the greatest impact on treatment performance and ii) the environmental conditions that are limiting the treatment performance in arctic WSPs, and the investigation does not aim to represent the model as an engineering design tool. Omissions of phytoplankton respiration and anaerobic processes were based on heuristics. Extended daylight during the summer in the North, allowing for continual photosynthesis, was the justification for the removal of phytoplankton respiration from the model, and the relative low activity of anaerobic processes when temperatures are less than $20^{\circ} \mathrm{C}$, as observed (Ragush et al. 2015; Ragush et al. 2017) in arctic WSPs, justified omission of anaerobic processes The model is a box model of the photic zone, and state variables and parameters were vertically-integrated over the depth of the photic zone. External forcing into the photic zone were additional wastewater, and surface irradiance. Exports from the photic zone were bacteria and phytoplankton through sinking. Gas exchange of oxygen and carbon dioxide between the atmosphere and photic zone was included as a transboundary interaction. Within the photic zone, the dynamics of bacteria and phytoplankton populations and their metabolites of oxygen, carbon dioxide, and carbon (in the form of $\mathrm{CBOD}_{5}$ ) were modeled. Nutrients other than carbon, such as nitrogen and phosphorous, were excluded because their concentrations in both field scale and experimental WSPs are high, and it was assumed that they would not impact biological processes by being limiting (Ragush et al. 2015; Ragush et al. 2017).

The model formulation discussed in the following section will refer to equations by their number denoted in Tables 1 and 2 (for example Table 1 Equation 1 will be represented as equation 1.1 in the text). Table 1 contains the system of differential equations, while Table 2 contains the supporting equations. Table 3 provides a list of model parameters and their description. MATLAB, version R2015b, by MathWorks (Masschusetts, USA) was used to implement a numerical solution to the system of ordinary differential equations presented in Table 1 . The system of ordinary differential equations is briefly discussed in section 2.1.1 and selected equations in Table 2 are discussed 


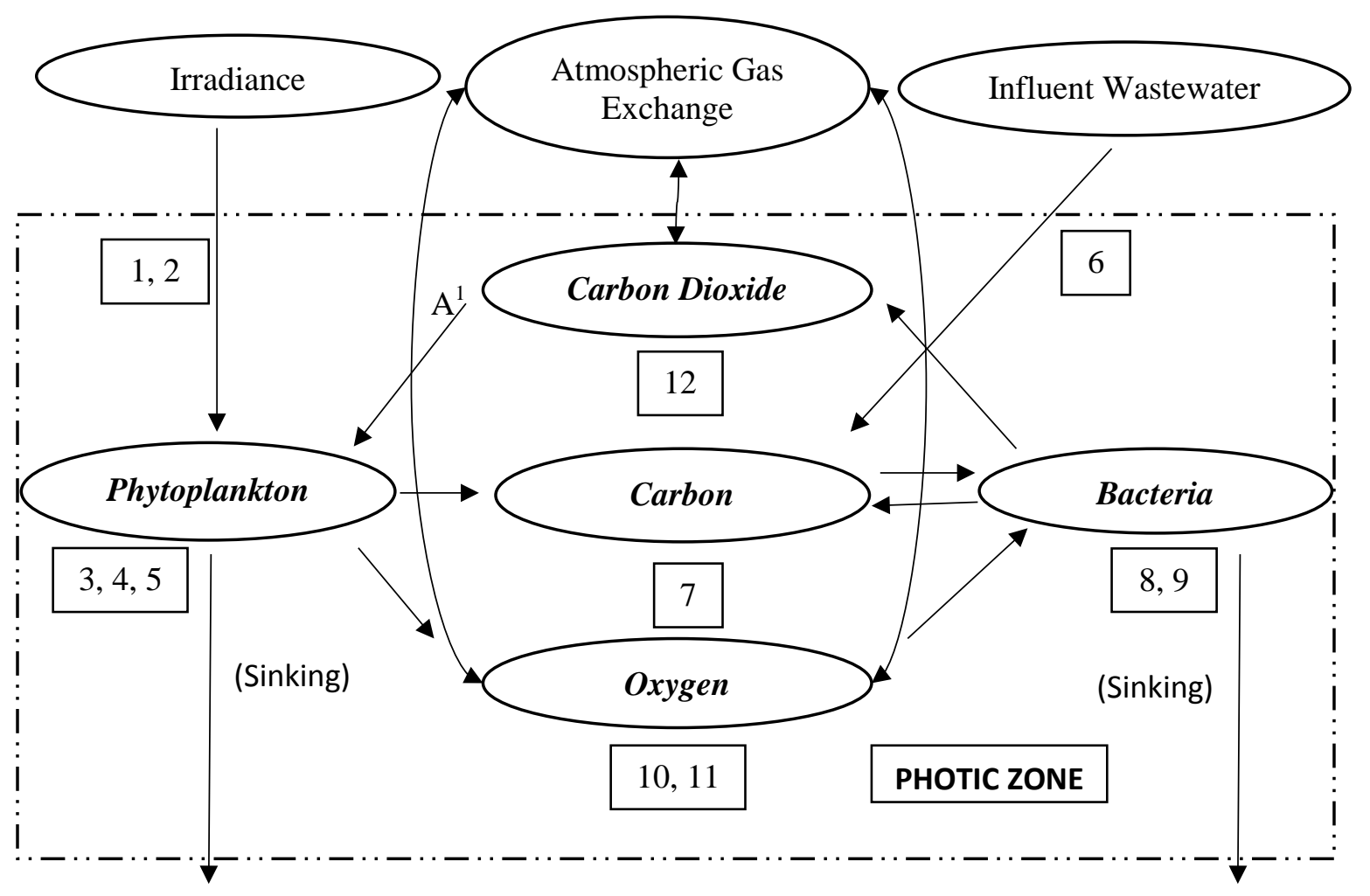

Figure 1 Diagram of modeled processes with listed applicable equations next to process arrows. $A^{1}$ Respiration of phytoplankton omitted because of net uptake of $\mathrm{CO}_{2}$ and continual solar irradiance leads to the potential of uninterrupted photosynthesis. Bold and Italicized text denotes state variables.

Table 1 List of Ordinary Differential Equations (ODEs) with brief descriptions.

\begin{tabular}{ccc}
\hline$\#$ & Equation & Description \& Comments \\
\hline 1 & $\frac{d A}{d T}=\left(U_{a}-K_{a d}-K_{a s}\right) * A$ & $\begin{array}{c}\text { Rate of change in phytoplankton = (specific rates of } \\
\text { Growth - death - settling) * phytoplankton density }\end{array}$ \\
\hline 2 & $\frac{d S}{d T}=-(O U R) * B+L * \frac{C B O D 5 i n f}{V} * \frac{\text { ColumnZ }}{Z}+K_{a d} *$ & $\begin{array}{c}\text { Rate of change in } \mathrm{CBOD}_{5} \text { = consumption by } \\
\text { bacteria + daily loading + inputs from } \\
\text { phytoplankton death + inputs from bacteria death }\end{array}$ \\
\hline 3 & $\frac{d B}{d t}=\left(U_{B}-K_{b d}-K_{b s}\right) B$ & $\begin{array}{c}\text { Rate of Change in bacteria = (rates of growth - } \\
\text { death - settling) * bacteria density }\end{array}$ \\
\hline 4 & $\frac{d O_{2}}{d t}=Y_{o a} * U_{a} * A-(O U R) * B+K l_{O_{2}} * \frac{A r e a}{V}$ & $\begin{array}{c}\text { Rate of Change of oxygen = Oxygenation by } \\
\text { phytoplankton - Consumption by bacteria } \\
\text { +aeration }\end{array}$ \\
\hline
\end{tabular}




\begin{tabular}{cc}
\hline$\frac{d C O_{2}}{d t}=\frac{Y c b}{Y_{o b}} *(\mathrm{OUR}) * B-Y_{c a} * U_{a} * \mathrm{~A}+\mathrm{Kl}_{\mathrm{CO}_{2}} *$ & $\begin{array}{c}\text { Rate of Change in carbon dioxide }=\text { production by } \\
\text { bacteria }- \text { consumption by phytoplankton }+ \\
\text { area }\end{array}$ \\
$\mathrm{V}$ & aeration \\
\hline
\end{tabular}

Table 2 List of supporting model equations and brief descriptions.

\begin{tabular}{|c|c|c|}
\hline \# & Equation & Description \& Comments \\
\hline 1 & $I a v=I o \frac{\left.1-e^{\left(-\left(K_{w}+K_{p} * A\right) * Z_{1 \%}\right.}\right)}{\left(K_{w}+K_{p} * A\right) * Z_{1 \%}}$ & $\begin{array}{l}\text { Average Irradiance across depth (considering } \\
\text { shading by phytoplankton) }\end{array}$ \\
\hline 2 & $z_{1 \%}=\frac{\log (0.01)}{-K_{w}}$ & $\begin{array}{c}\text { Depth of 1\% light transmittance (negating } \\
\text { phytoplankton) }\end{array}$ \\
\hline 3 & $F d i s=(1-E D) *\left(1-e^{-4 e^{-(A G S) A}}\right)+E D$ & $\begin{array}{c}\text { Growth inhibition of phytoplankton as caused by } \\
\text { crowding } \\
\text { (Gompertz logistic growth model) }\end{array}$ \\
\hline 4 & $U_{a}=U \max * F_{d i s} * \frac{\mathrm{CO}_{2}}{K_{\mathrm{CO}_{2}}+\mathrm{CO}_{2}} * \frac{I a v}{I a v+I_{\text {halfsat }}}$ & $\begin{array}{c}\text { Growth rate of phytoplankton }= \\
\text { (Maximum phytoplankton growth rate * Crowding } \\
\text { limitation } * \mathrm{CO}_{2} \text { limitation } * \text { Light Limitation) }\end{array}$ \\
\hline 5 & $\mathrm{CBOD}_{5 \mathrm{inf}}=\mathrm{RAW} * \mathrm{SOL}_{\mathrm{CBOD} 5}$ & $\begin{array}{c}\text { Addition of } \mathrm{CBOD}_{5} \text { into photic zone }=\mathrm{CBOD}_{5} \\
\text { concentration } * \text { solubility }\end{array}$ \\
\hline 6 & $U_{b}=\operatorname{Umax}_{b} * \frac{S}{K_{S}+S} * \frac{O_{2}}{K_{O_{2}}+O_{2}} *(1-B G S * B)$ & $\begin{array}{c}\text { Growth rate of bacteria rate } \\
\text { Maximum bacteria growth rate * carbon substrate } \\
\text { limitation * Oxygen limitation * self-limitation } \\
\text { (logistic growth) }\end{array}$ \\
\hline 7 & $\begin{array}{c}\text { If } \mathrm{d} O_{2}>O U R_{b} * \\
(O U R)=(O U R)_{m} * \frac{O_{2}}{O_{2} * K_{O_{2}}}+(O U R)_{b} \\
\text { else } \\
(O U R)=\frac{O_{2}}{B}\end{array}$ & $\begin{array}{l}\text { Oxygen utilization rate: depends on the available } \\
\text { oxygen and the bacterial population density }\end{array}$ \\
\hline 8 & $\mathrm{CBOD}_{5}(\mathrm{t})=\mathrm{S}(\mathrm{t})+0.5^{*}(\mathrm{~A}(\mathrm{t}))$ & $\begin{array}{l}\mathrm{CBOD}_{5}=\text { Carbon pool } \mathrm{CBOD}_{5}+\mathrm{CBOD}_{5} \text { of } \\
\text { phytoplankton ((t) denoting at time t for clarity) }\end{array}$ \\
\hline
\end{tabular}

\begin{tabular}{ccc}
\hline Symbol & Definition & Value \& Units \\
\hline & State Variables & \\
\hline $\mathrm{A}$ & Average phytoplankton concentration (algae) & $\mathrm{mg} / \mathrm{l}$ (wet mass) \\
\hline $\mathrm{B}$ & Bacteria concentration & $\mathrm{mg} / \mathrm{l}$ (wet mass) \\
\hline $\mathrm{S}$ & Substrate concentration (carbon) & $\mathrm{mg} / \mathrm{l}\left(\mathrm{CBOD}_{5}\right)$ \\
\hline $\mathrm{O}_{2}$ & Oxygen concentration & $\mathrm{mg} / \mathrm{l}$ \\
\hline $\mathrm{CO}_{2}$ & Carbon dioxide concentration & $\mathrm{mg} / \mathrm{l}$ \\
\hline & Variables & Unitless \\
\hline $\mathrm{F}_{\mathrm{dis}}$ & $\begin{array}{c}\text { Reduction in phytoplankton growth due to } \\
\text { preferred distribution reducing irradiance }\end{array}$ & $\frac{\mu \mathrm{E}}{\mathrm{m}^{2} \mathrm{~s}}$ \\
\hline $\mathrm{I}_{\mathrm{av}}$ & $\begin{array}{c}\text { Average irradiance across photic depth (Z) } \\
\text { with phytoplankton }\end{array}$
\end{tabular}




\begin{tabular}{|c|c|c|}
\hline & Constants & \\
\hline $\mathrm{CBOD}_{\text {5inf }}$ & Influent CBOD5 concentration & $550 \mathrm{mg} / \mathrm{l}$ \\
\hline $\mathrm{Z}$ & Depth of water column (total depth) & $1.25 \mathrm{~m}$ \\
\hline $\mathrm{Cs}_{\mathrm{O} 2}$ & Saturation concentration oxygen & $\begin{array}{c}11.3 \mathrm{mg} / 1\left(5^{\circ} \mathrm{C}\right) 8.9 \mathrm{mg} / \mathrm{l}\left(15^{\circ} \mathrm{C}\right) \\
\text { NIST (2015) }\end{array}$ \\
\hline $\mathrm{Cs}_{\mathrm{CO} 2}$ & Saturation concentration carbon dioxide & $\begin{array}{c}1.01 \mathrm{mg} / \mathrm{l}\left(5{ }^{\circ} \mathrm{C}\right) 0.75 \mathrm{mg} / \mathrm{l}\left(15^{\circ} \mathrm{C}\right) \\
\text { Benson \& Krause }(1984)\end{array}$ \\
\hline $\mathrm{L}$ & Daily volumetric loading & 0.0125 or $0.05 \mathrm{l} / \mathrm{d}$ \\
\hline $\mathrm{I}_{\mathrm{av}}$ & $\begin{array}{l}\text { Average irradiance across photic depth (Z) } \\
\text { with no phytoplankton }\end{array}$ & $($ Eqn 1$) \frac{\mu \mathrm{E}}{\mathrm{m}^{2}} \mathrm{~s}^{-1}$ \\
\hline $\mathrm{I}_{0}$ & Surface incident light & $225 \& 1050 \frac{\mu \mathrm{E}}{\mathrm{m}^{2}} \mathrm{~s}^{-1}$ \\
\hline $\mathrm{K}_{\mathrm{w}}$ & Attenuation coefficient of the wastewater & $14 \mathrm{~m}^{-1}$ \\
\hline $\mathrm{SOL}_{\text {CBOD5 }}$ & Solubility Ratio of $\mathrm{CBOD}_{5}$ & 0.5 \\
\hline $\mathrm{V}$ & Volume & $0.0228 \mathrm{~m}^{3}$ \\
\hline $\mathrm{z}_{1 \%}$ & Photic zone depth (1\% measured irradiance) & $($ Eqn 2) $\mathrm{m}$ \\
\hline
\end{tabular}

151

*Manually calibrated constants provided in Table 3

\subsubsection{State Variables and Ordinary Differential Equations}

The model has five state variables: phytoplankton, bacteria, carbon, oxygen, and carbon dioxide, and the first four were measured in the mesocosm study by Ragush et al. (2017), which were used to create a system of Ordinary Differential Equations represented in Table 1 and briefly discussed below:

$$
\frac{d A}{d T}=\left(U_{a}-K_{a d}-K_{a s}\right) * A(1.1)
$$

“A” represents phytoplankton (algae) as is used in many ecological models. The growth of phytoplankton population is the balance of its growth rate $\left(U_{a}\right)$ with some loss rates separated into death $\left(K_{a d}\right)$ and settling $\left(K_{a s}\right)$. The impact of death and settling has no mathematic functional difference and can be lumped with the same effect. They were separated here, as it is a common practice in ecological models.

$$
\frac{d S}{d T}=-(O U R) * B+L * \frac{C B O D \operatorname{sinf}}{V} * \frac{Z}{Z_{1 \%}}+K_{a d} * A * 0.5+K_{b d} * 0.7 * \mathrm{~B}(1.2)
$$

"S" commonly represents substrate in ecological models; here it represents $\mathrm{CBOD}_{5}$. The substrate is consumed by the bacteria in a stochiometric balance of the bacteria's oxygen utilization rate (OUR). Additional $\mathrm{CBOD}_{5}$ is added daily, as wastewater is added to the system, and CBOD5 is recycled in the death of phytoplankton (A) and bacteria (B) according to stochiometric carbon compositions.

$$
\frac{d B}{d t}=\left(U_{B}-K_{b d}-K_{b s}\right) B(1.3)
$$


“B”, Bacteria is controlled analogously to phytoplankton with growth rate $\left(\mathrm{U}_{\mathrm{b}}\right)$, death rate $\left(\mathrm{K}_{\mathrm{bd}}\right)$, and settling rate $\left(\mathrm{K}_{\mathrm{bs}}\right)$.

$$
\frac{d O_{2}}{d t}=Y_{o a} * U_{a} * A-(O U R) * B+K l_{O_{2}} * \frac{\text { Area }}{V} *\left(C s_{O_{2}}-O_{2}\right)(1.4)
$$

The differential equation for oxygen is governed by photosynthesis of phytoplankton, the utilization by bacteria and finally oxygen transfer rate across the quiescent surface.

$$
\frac{d C O_{2}}{d t}=\frac{Y_{b c}}{Y_{b o}} *(O U R) * B-Y_{a c} * U_{a} * \mathrm{~A}+K l_{C O_{2}} * \frac{\text { Area }}{V} *\left(C S_{C_{2}}-C O_{2}\right) \text { (1.5) }
$$

Analogous to the equation for oxygen, the equation for carbon dioxide includes production from bacteria, uptake from phytoplankton and carbon dioxide transfer across the surface.

Graphs are provided to compare the experimental and modelling result in figures 3 and 4 for carbon (measured through $\mathrm{CBOD}_{5}$ ) and dissolved oxygen, respectively. A graph of the phytoplankton and bacteria results are provided for the most interesting case scenario of $80 \mathrm{mg} / \mathrm{l}$ initial $\mathrm{CBOD}_{5}$ and $15{ }^{\circ} \mathrm{C}$ environmental temperature in Figure $\mathrm{S} 1$ in the supplemental material. The model includes the state variable of carbon dioxide, however, no data was available to create a comparison for this state variable, as this parameter was not measured by Ragush et al. (2017). Carbon dioxide was included as a state variable because a state limitation was required to explain the decrease of phytoplankton and bacteria populations in the later stage of some trials (Supplemental 1). Typically, a light limitation would be expected to have caused the limit on population, however in this model with no mixing it would result in a steady state phytoplankton population, and this was not observed. Since the decrease in phytoplankton and bacteria populations coincided with the decrease in available organic carbon, it was hypothesized to be an organic carbon/carbon dioxide limitation. It is noteworthy that carbon dioxide limitation has been identified as a cause of phytoplankton population crashes in waste stabilization ponds (Shilton 2005). The authors recognize the possibility that an alternative reason could be a micronutrient as the limiting agent, and the hypothesis that it is carbon dioxide warrants further investigation. However, the existence of a different limiting agent has negligible impact on the goals of this investigation and only a minor reformulation of the model would be required to accommodate this realization.

The authors recognize that this model simplifies the complex inorganic carbon dynamics and does not explicitly consider the potential uptake of other inorganic carbon species such as bicarbonate by phytoplankton. The data does 
193

194

195

not exist to justify the incorporation of these complicating processes, and from a heuristic perspective their inclusion is outside the scope of the model. The authors see their inclusion as an avenue of investigation for future model improvements.

\subsection{Temperature}

The temperature dependences of chemical, physical and biological processes were modelled based on the van’t Hoff-Arrhenius relationship (equation 2.1) from Metcalf \& Eddy (2003) who used a range of 1.024 -1.08 for $\theta$ (equivalent to an approximate $\mathrm{Q}_{10}$ of 1.3-2.2) for biological processes. For the physical process of aeration Elmore and West (1961) suggests a value of 1.024 (equivalent). Due to lack of data, and to maintain simplicity and focus of the study, all temperature dependent processes were modelled with a $\theta$ of 1.024 except the phytoplankton maximum growth rate. The van't Hoff-Arrhenius relationship was not applied to phytoplankton maximum growth rate because literature supported a larger temperature dependence, and Dauta et al. (1990) estimated maximum phytoplankton growth rates of 0.3 day $^{-1}$ at $5{ }^{\circ} \mathrm{C}$ and 0.72 day $^{-1}$ at $15{ }^{\circ} \mathrm{C}$ : equivalent to a $\mathrm{Q}_{10}$ of 2.4 . During our study, the phytoplankton growth rates were calibrated to 0.32 day $^{-1}$ at and 0.75 day $^{-1}$ at $5{ }^{\circ} \mathrm{C}$ and $15{ }^{\circ} \mathrm{C}$; values remarkably close to those recorded by Dauta et al. (1990). The model was found to be insensitive to any change in the growth rate of bacteria in the range of literature values (Tables 5 \& 6).

$$
\text { Rate }_{\text {Temperature }}=\text { Rate }_{20 C} * \theta^{(T-20)}
$$

\subsection{Phytoplankton}

Modeling of phytoplankton populations and their growth must account for the vertical distribution of the population and the vertical gradients in irradiance, nutrients, and metabolites. As our system represents a special case of high light attenuation, limited vertical mixing forces, and high nutrients, phytoplankton growth was formulated on the premise that the phytoplankton population has the ability to optimize its growth rate and will distribute itself accordingly. The formulation is significantly different than common formulations used for well-mixed environments such as in Huisman and Weissing (1994). The deviation was out of a necessity as it was discovered that the unique environmental conditions required approaching the problem from a different paradigm. Sections 2.3 focuses on the process by which the novel formulation for phytoplankton growth was developed to describe the arctic WSP. The development of the mathematical characterization of the depth integrated phytoplankton response for a WSP 
requires careful consideration of three factors: i) phytoplankton-light response ii) population density limited growth, and iii) photoinhibition.

221

\subsubsection{Phytoplankton light response}

Solar radiation provides the energy for photosynthesis, and the total (vertically integrated) phytoplankton production will be proportional to the amount of energy absorbed by the phytoplankton. Not all of the irradiance that reaches the surface of the water column can be utilized by the phytoplankton because light energy is also absorbed or reflected by particles. Additionally, light photons are absorbed by the phytoplankton cells themselves, reducing the available irradiance to other cells (specifically at greater depth) and as the vertically integrated population density increases the available irradiance per individual must decrease, and is known as self-shading. Finally, the response of the depth-integrated phytoplankton population in the photic zone is assumed to be related to the average irradiance in the photic zone by a hyperbolic function.

The transmittance of light has been demonstrated to be successfully approximated to follow exponential decay with distance through a media, and is commonly described by Beer-Lambert's law:

$$
I_{z}=I_{o} e^{-k z}
$$

Where: $\mathrm{I}_{\mathrm{o}}=$ irradiance at surface (depth $\left.0 \mathrm{~m}\right), \mathrm{I}_{\mathrm{z}}=$ irradiance at depth $\mathrm{z}\left(\mu \mathrm{E} / \mathrm{m}^{2} / \mathrm{s}\right), \mathrm{k}=$ attenuation coefficient $\left(\mathrm{m}^{-1}\right)$, and $\mathrm{z}=$ depth (m)

The attenuation coefficient is a water quality property i.e. an expression of color and suspended solids (Lorenzen 1972). When modeling vertically varying phytoplankton growth, it is common to define the euphotic zone depth, as the depth where $1 \%$ of the surface light may be measured in a water column with attenuation properties of $\mathrm{k}$ :

$$
-\frac{\operatorname{Ln}(0.01)}{k}=z_{1 \%} \quad \text { (2.2) (Lorenzen 1972) }
$$

Phytoplankton concentrations change with depth and time, and therefore $\mathrm{k}$ was split into two contributors; $\mathrm{k}_{\mathrm{w}}$ (considered a property of the water and its constituents), and $\mathrm{k}_{\mathrm{p}}$ (accounts for the absorption of light by phytoplankton). 
Where: $\mathrm{k}_{\mathrm{w}}=$ Light attenuation coefficient of water and constituents $\left(\mathrm{m}^{-1}\right), \mathrm{k}_{\mathrm{p}}=$ Light attenuation coefficient of phytoplankton $\left(\mathrm{m}^{-1} /[\mathrm{mg} / \mathrm{l}]\right)$, and $\mathrm{A}=$ phytoplankton concentration $(\mathrm{mg} / \mathrm{l})$
$\mathrm{k}_{\mathrm{w}}$ and $\mathrm{k}_{\mathrm{p}}$ were considered homogenous and constant over the duration of the simulation.

The average light in the photic zone (between the surface and $\mathrm{Z}_{1 \%}$ ) can be approximated by incorporating attenuation into Beer-Lambert's law and integrating over the photic zone and averaging over the depth:

$$
I a v=\frac{1}{z_{1} \%} \int_{0}^{z_{1} \%} I_{o} e^{-k z}=\frac{1-\mathrm{e}^{-\left(\mathrm{k}_{w}+\mathrm{p} * \mathrm{~A}\right)\left(\mathrm{z}_{1} \%\right)}}{\left(\mathrm{k}_{w}+\mathrm{k}_{p} * \mathrm{~A}\right) \mathrm{z}_{1} \%}
$$

Note that in this formulation of the production-irradiance relationship average irradiance and phytoplankton values are used, and results in an average growth rate in the photic zone. Although neither the phytoplankton concentration nor the irradiance is constant with depth, an appropriately parameterized box model is not compromised by using the average values; however, the parameterization is likely to be impacted (Behrenfeld \& Falkowski 1997). The average irradiance in the photic zone was used in the Michaelis-Menten equation for the production-irradiance response of phytoplankton (Equation 4) with the half saturation constant of Chlorella vulgaris as reported by Dauta et al. (1990). Alternatively, it was found that the exponential formulation for the phytoplankton-irradiance curve (1-exp($\left.\alpha \mathrm{I}_{\mathrm{av}} / \mathrm{U}_{\max }\right)$ ) can be substituted with a value of 0.016 for $\alpha / \mathrm{Umax}$ (assumed constant with temperature) with no impact on model results.

\subsubsection{Phytoplankton Distribution}

If light was the only controlling factor of phytoplankton growth, it would be optimal for phytoplankton to grow in large concentrations over a narrow depth where irradiance was optimal. Although phytoplankton populations predictably reside in greatest concentrations near the depth of optimal irradiance (assuming no nutrient limitations) (Mellard et al. 2011), as the population grows the vertical range inhabited expands out from the area of optimal irradiance (Klausmeier and Litchman 2001). The physiological causes for this broadening of the vertical population structure were not identified in this study, however the authors postulate that it is biological stressors related to limitations in extracellular mass transfer rates (diffusion) of metabolites, such as carbon dioxide, oxygen, and nutrients that create this vertical distribution. We assume phytoplankton can only obtain their maximum growth rate at low population densities, when nutrients and light are abundant and the stressors associated with high population 
densities are not present. We propose that the impact of self-limitation of phytoplankton growth is a critical element in modeling phytoplankton dynamics in nutrient rich systems with minimal vertical mixing. Populations that experience self-limitation with density are commonly described with logistic growth models, and in our model we

271 utilized a generalized logistic growth model, the Gompertz model $\left(\mathrm{F}_{\mathrm{dis}}\right)$. The Gompertz model has been utilized

272 extensively in the modelling of bacteria populations (Contois, 1959, Zwietering et al. 1990), however the function is

273 difficult to visualize, and so a plot of $\mathrm{F}_{\text {dis }}$ (Figure 2) has been provided to clearly depict the response of this function

274 and demonstrate how it represents the aforementioned goals. The parameters of $F_{\text {Dis, }}$ AGS (Phytoplankton Growth

275 Self-suppression) and ED (Equal Distribution), can be estimated through review of literature, however AGS and ED

276 were largely used in calibration of the model because more experimentation of the relationship between

277 phytoplankton density and phytoplankton growth is needed. The resulting formulation is:

$$
\text { Fdis }=(1-E D) *\left(1-\mathrm{e}^{-4 \mathrm{e}^{-(\text {AGS }) \mathrm{A}}}\right)+\mathrm{ED}(2.3)
$$




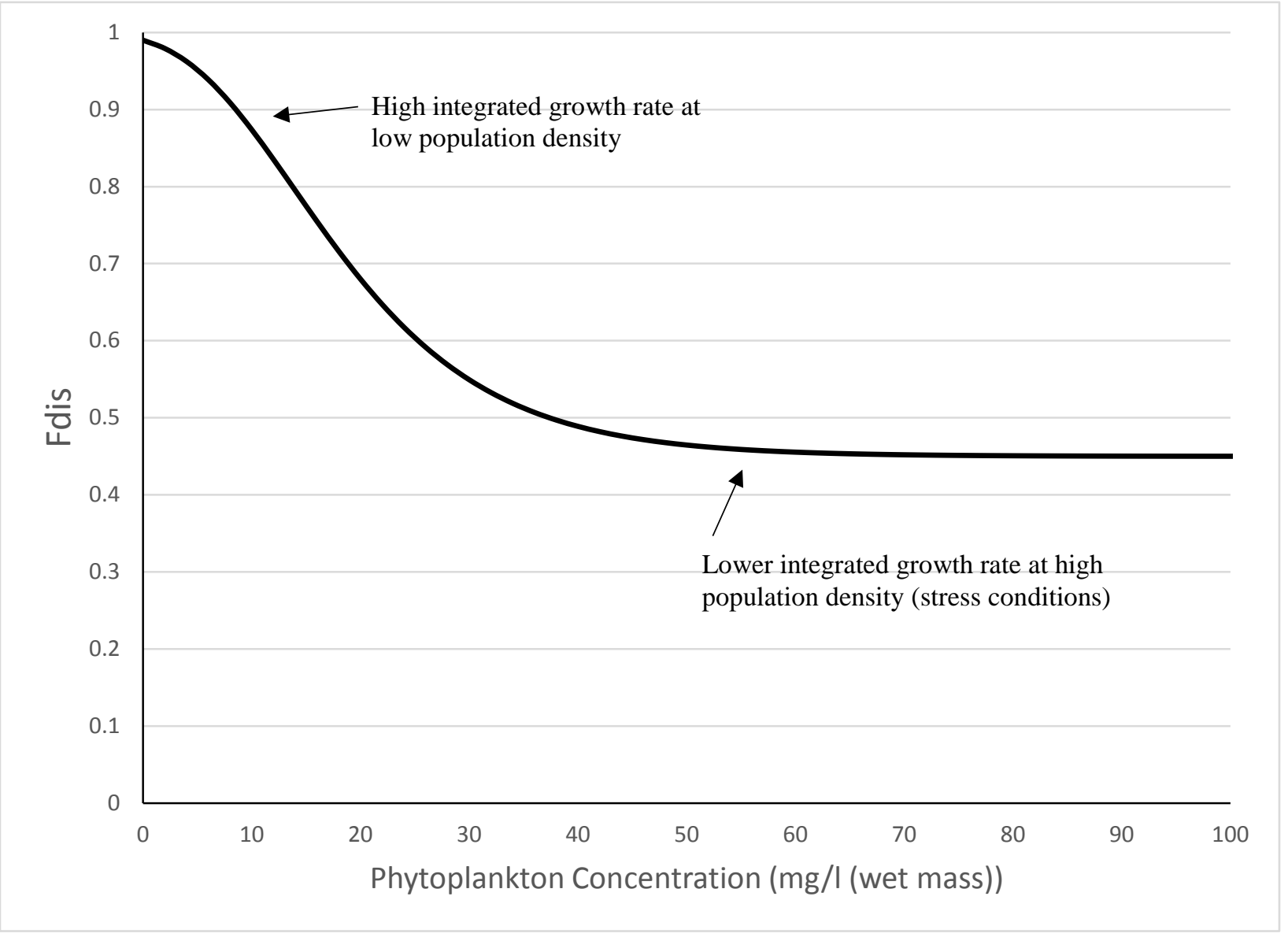

Figure 2. Representation of the changes in integrated phytoplankton growth rate (Fdis) with increasing phytoplankton concentration.

\subsubsection{Photoinhibition}

285 The growth rate of phytoplankton increases with increasing irradiance until an optimal irradiance results in a 286 maximum growth rate, after which a decline in growth rate is typically observed (Dauta et al., 1990). The 287 observation of such as photoinhibition has been documented in small batch reactors where phytoplankton are 288 confined and subjected to high irradiance. However, photoinhibition is the result of a phytoplankton’s inability to 289 remove the stressor of excessive irradiance and UV radiation forming harmful reactive oxygen species, and it can be rationalized that provided the phytoplankton has adequate (i) space and (ii) mobility, they will avoid photoinhibition

291 by migrating towards lower-light levels where their growth is optimized. This would result in a threshold irradiance 292 where, the vertically integrated specific growth rate has reached a satiated maximum and is an implicit 
representation of photoinhibition. The authors note that the exclusion of explicit photoinhibition is specific to a case where currents or mixing do not overwhelm the phytoplankton’s mobility and the growth of phytoplankton is integrated over a control depth.

\subsection{Bacteria}

A logistic growth model (Equation 8), with a death term was used to describe heterotrophic bacteria growth. Bacterial growth suppression (BGS) is approximately the inverse of the carrying capacity, as BGS multiplied by the maximum bacteria population will provide a value of 1, resulting in bacterial growth rate of zero. The aerobic metabolism was based on an oxygen utilization rate (OUR) (units of $\mathrm{mg} \mathrm{O}_{2} / \mathrm{mg}$ bacteria day ${ }^{-1}$ ) that consisted of the basal oxygen utilization rate ( our $_{\mathrm{b}}$ ) required to sustain the existing population, and an additional oxygen utilization rate $\left(\right.$ our $\left._{\mathrm{m}}\right)$ required for the population to grow (Equation 10). It was reasoned that in the case there was less oxygen available than desired by the bacteria, the bacteria would use all the oxygen (resulting in an OUR equal to the available oxygen concentration divided amongst the bacteria concentration). The model does not consider the potential for anaerobic growth of bacteria. The removal of $\mathrm{CBOD}_{5}$ was equivalent to the amount of oxygen used, and the production of $\mathrm{CO}_{2}$ was computed based on the stoichiometry of carbon dioxide produced for every unit of oxygen used $\left(\mathrm{Y}_{\mathrm{bc}} / \mathrm{Y}_{\mathrm{bo}}\right)$.

\subsection{Carbon Cycling}

Phytoplankton and bacteria return carbon back into the organic pool upon death (Equation 7). From literature, it was estimated that $1 \mathrm{mg}$ of dry phytoplankton mass has a chemical oxygen demand (COD) of $1 \mathrm{mg}$ (Boyd 1973) and

The general relationship of $1 \mathrm{mg} / \mathrm{lCBOD}_{5}: 2 \mathrm{mg} / \mathrm{l} \mathrm{COD}$ was used resulting in $0.5 \mathrm{mg} \mathrm{CBOD}_{5} / \mathrm{mg}$ phytoplankton and $0.7 \mathrm{mg} \mathrm{CBOD}{ }_{5} / \mathrm{mg}$ bacteria. Additionally, the $\mathrm{CBOD}_{5}$ of the phytoplankton was also accounted for in equation 13 by adding the $\mathrm{CBOD}_{5}$ of the phytoplankton to the $\mathrm{CBOD}_{5}$ of the organic pool. Bacteria was omitted from being considered in the $\mathrm{CBOD}_{5}$ pool because it forms the community that is responsible for the utilization of oxygen within the $\mathrm{CBOD}_{5}$ test and therefore cannot be enumerated. 


\section{Results and Discussion}

318 The model was used to investigate the experimental results from Ragush et al. (2017). In the experiment, mesocosms representative of arctic WSPs were constructed to assess the impact of temperature, irradiance, organic loading rate, and initial organic concentration. The experiment was run either until steady state of oxygen and $\mathrm{CBOD}_{5}$ were achieved or for 40 days. The populations of phytoplankton and bacteria, and $\mathrm{CBOD}_{5} \mathrm{Concentration}$ were measured every 5-7 days while dissolved oxygen concentration was measured daily. The system was operated in a manner that is analogous to systems in the North, with daily loading of carbon and nutrients being imitated with a complex synthetic wastewater. Temperature and irradiance were maintained as constants for the duration of trials. The water level was maintained through the addition of distilled water to replace evaporated volume to remove the impact of any concentrating effect.

\subsection{Model Calibration and Performance}

Experimental results from Ragush et al. (2017) were used to calibrate the model. The calibration was performed by fitting the model to the experimental results of $\mathrm{CBOD}_{5}$ and dissolved oxygen concentrations obtained at $5^{\circ} \mathrm{C}$, and then validating against experimental results generated at $15{ }^{\circ} \mathrm{C}$. Maximum phytoplankton growth rates (Umax $\left.{ }_{a}\right)$ were set to the values provided by Dauta et al. (1990). Umax ${ }_{a}$ was then calibrated at both temperatures, however, the calibration values (0.32 and 0.75 days $^{-1}$ at 5 and $15^{\circ} \mathrm{C}$, respectively) represented only a minor adjustment from

333 growth rates (0.3 and 0.7 days $^{-1}$ ) provided by Dauta et al. (2010). The model was calibrated at both temperatures 334 with a $240 \mathrm{mg} / \mathrm{l}$ initial carbon concentration, and validated at $80 \mathrm{mg} / \mathrm{l}$ initial carbon concentration. The values of the calibrated parameters are provided in Table 4 . Figures 3 and 4 depict the model predicted (lines) and experimental observed (symbols) $\mathrm{CBOD}_{5}$ and dissolved oxygen concentrations, respectively, under the different temperature and initial loading conditions and show that the model is able to capture the general trends and effectively distinguishes system dynamics for the various conditions. Such qualitative model-data comparison is sufficient for the purposes of this paper, which focuses on exploration of the parameterization and impact of different environmental conditions.

Table 4. Manually calibrated model parameters.

\begin{tabular}{cccc}
\hline Parameter & Definition & Units & Value \\
\hline Ihalfsat & $\begin{array}{c}\text { Irradiance half } \\
\text { saturation of } \\
\text { phytoplankton }\end{array}$ & $\frac{\mu \mathrm{E}}{\mathrm{m}^{2}} \mathrm{~s}^{-1}$ & 30 \\
\hline
\end{tabular}




\begin{tabular}{|c|c|c|c|}
\hline $\mathrm{K}_{\mathrm{ad}}$ & $\begin{array}{l}\text { Phytoplankton } \\
\text { death rate }\end{array}$ & day $^{-1}$ & 0.05 \\
\hline $\mathrm{K}_{\mathrm{as}}$ & $\begin{array}{l}\text { Phytoplankton } \\
\text { settling }\end{array}$ & day $^{-1}$ & 0.05 \\
\hline $\mathrm{K}_{\mathrm{bd}}$ & Bacteria death rate & day $^{-1}$ & 0.025 \\
\hline $\mathrm{K}_{\mathrm{bs}}$ & Bacteria settling & day $^{-1}$ & 0 \\
\hline $\mathrm{K}_{\mathrm{CO} 2}$ & $\begin{array}{c}\text { Half saturation of } \\
\text { phytoplankton on } \\
\text { carbon dioxide }\end{array}$ & $\frac{\mathrm{mg} \mathrm{CO}}{\mathrm{l}}$ & 0.044 \\
\hline $\mathrm{K}_{\mathrm{O} 2}$ & $\begin{array}{c}\text { Half saturation of } \\
\text { bacteria on oxygen }\end{array}$ & $\frac{\mathrm{mg} \mathrm{O}_{2}}{\mathrm{l}}$ & 0.256 \\
\hline $\mathrm{K}_{\mathrm{p}}$ & $\begin{array}{l}\text { Light abstraction } \\
\text { by phytoplankton }\end{array}$ & $\frac{\mathrm{m}^{-1}}{\mathrm{mg} / \mathrm{l}}$ & 0.13 \\
\hline $\mathrm{Kl}_{\mathrm{CO} 2}$ & $\begin{array}{l}\text { Carbon Dioxide } \\
\text { transfer rate } \\
\text { (piston velocity) }\end{array}$ & $\frac{\mathrm{m}}{\mathrm{day}}$ & $0.17\left(@ 20{ }^{\circ} \mathrm{C}\right)$ \\
\hline $\mathrm{Kl}_{\mathrm{O} 2}$ & $\begin{array}{l}\text { Oxygen transfer } \\
\text { rate (piston } \\
\text { velocity) }\end{array}$ & $\frac{\mathrm{m}}{\mathrm{day}}$ & $0.17\left(@ 20^{\circ} \mathrm{C}\right)$ \\
\hline Ks & $\begin{array}{c}\text { Half saturation of } \\
\text { bacteria on } \\
\text { substrate } \\
\end{array}$ & $\frac{\mathrm{mg} \mathrm{CBOD}}{\mathrm{l}}$ & 80 \\
\hline our $_{\mathrm{b}}$ & $\begin{array}{c}\text { Basal oxygen } \\
\text { utilization rate of } \\
\text { bacteria }\end{array}$ & $\frac{\mathrm{mg} \mathrm{O}_{2}}{\mathrm{mg} \mathrm{bac}} \mathrm{day}^{-1}$ & $0.10\left(@ 20{ }^{\circ} \mathrm{C}\right)$ \\
\hline our $_{\mathrm{m}}$ & $\begin{array}{c}\text { Metabolic oxygen } \\
\text { utilization rate of } \\
\text { bacteria }\end{array}$ & $\frac{\mathrm{mg} \mathrm{O}_{2}}{\mathrm{mg} \mathrm{bac}} \mathrm{day}^{-1}$ & $0.55\left(@ 20^{\circ} \mathrm{C}\right)$ \\
\hline $\operatorname{Umax}_{a}$ & $\begin{array}{l}\text { Max growth rate } \\
\text { phytoplankton }\end{array}$ & day $^{-1}$ & $\begin{array}{c}0.75\left(@ 15{ }^{\circ} \mathrm{C}\right) \\
0.32\left(@ 5{ }^{\circ} \mathrm{C}\right) \\
\end{array}$ \\
\hline $\operatorname{Umax}_{\mathrm{b}}$ & $\begin{array}{c}\text { Max growth rate } \\
\text { bacteria }\end{array}$ & day $^{-1}$ & 5 \\
\hline Yac & $\begin{array}{c}\text { Yield factor of } \\
\mathrm{CO}_{2} \text { consumed per } \\
\text { a mg of } \\
\text { phytoplankton }\end{array}$ & $\frac{\mathrm{mg} \mathrm{CO}_{2}}{\text { mg Phytoplankton }}$ & 2.18 \\
\hline $\mathrm{Y}_{\mathrm{bc}} / \mathrm{Y}_{\mathrm{bo}}$ & $\begin{array}{l}\text { Carbon dioxide/ } \\
\text { oxygen produced }\end{array}$ & $\mathrm{mg} \mathrm{CO} / 2 \mathrm{mg} \mathrm{O}_{2}$ & 1.38 \\
\hline BGS & $\begin{array}{l}\text { Bacterial Growth } \\
\text { Self Suppression }\end{array}$ & $1 / \mathrm{mg}$ & 0.01 \\
\hline AGS & $\begin{array}{l}\text { Phytoplankton } \\
\text { growth Self } \\
\text { suppression } \\
\end{array}$ & Unitless & 0.1 \\
\hline ED & $\begin{array}{c}\text { Equal Distribution } \\
\text { Factor }\end{array}$ & Unitless & 0.45 \\
\hline
\end{tabular}




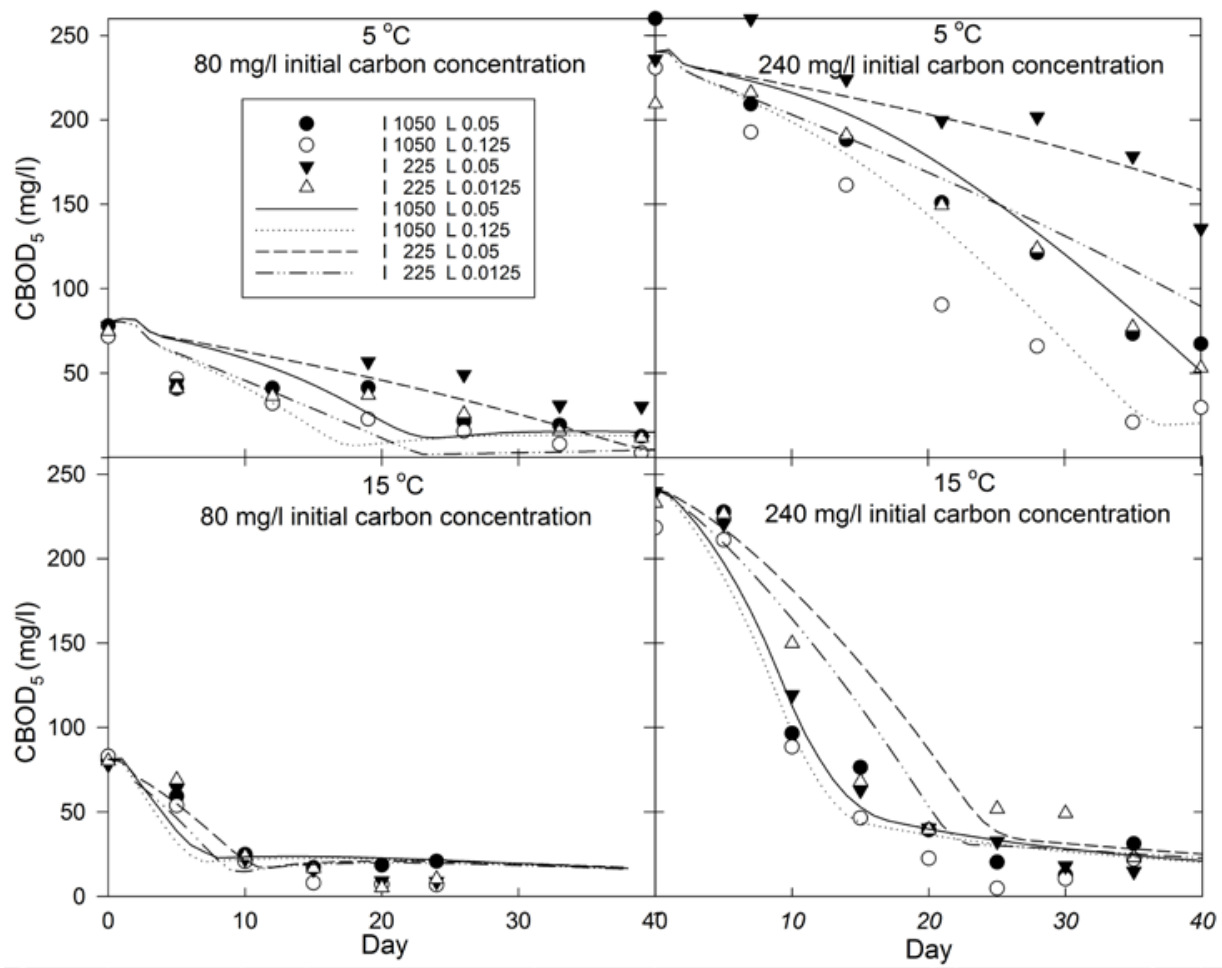

343
Figure 3. Concentrations of CBOD5 in model waste stabilization ponds operating at 5 or $15^{\circ} \mathrm{C}$ with different initial carbon concentrations (80 or $240 \mathrm{mg} / \mathrm{l}$ ). The model performance for CBOD5 concentration predictions under the different conditions is shown as lines, while the experimental results from Ragush et al. (2017) are shown as symbols. I denotes the modelled and experimental irradiance $\left(\mu \mathrm{E} / \mathrm{m}^{2} / \mathrm{s}\right)$ and $\mathrm{L}$ is the volumetric loading rate $\left(\mathrm{m}^{3} /\right.$ day), 


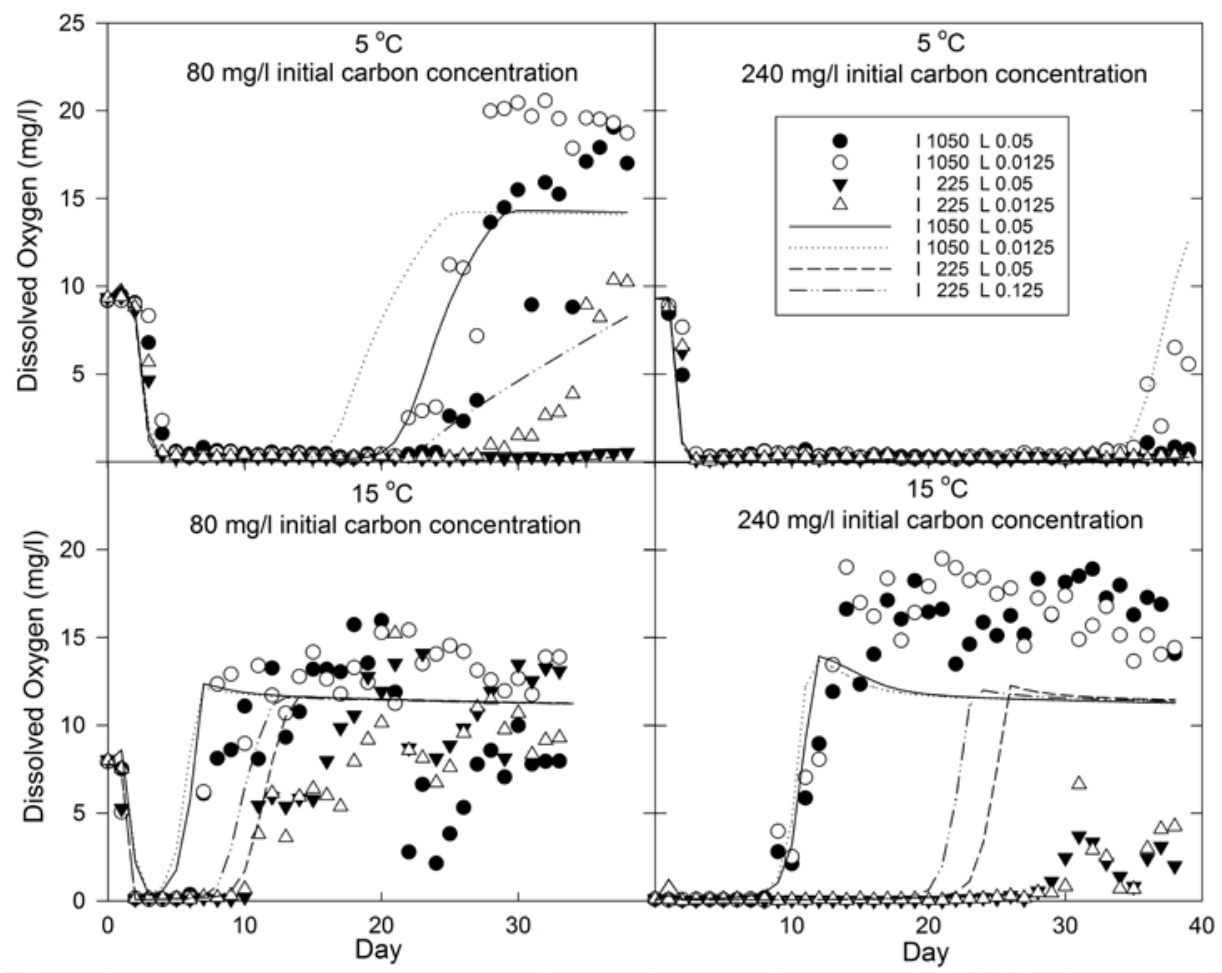

348

Figure 4. Dissolved oxygen concentrations in model waste stabilization ponds operating at 5 or $15^{\circ} \mathrm{C}$ with different initial carbon concentrations (80 or $240 \mathrm{mg} / \mathrm{l}$ ). The model performance for dissolved oxygen concentration predictions under the different experimental conditions are shown as line, while the experimental results from Ragush et al. (2017) are shown as symbols. I is the modelled and experimenal irradiance $\left(\mu \mathrm{E} / \mathrm{m}^{2} / \mathrm{s}\right)$ and $L$ is the volumetric loading rate $\left(\mathrm{m}^{3} /\right.$ day),

While in general, good qualitative agreement between model and experimental results was observed, several inconsistencies provide insight into areas that are not well represented by the model and require further research. For example, the model underestimated the maximum dissolved oxygen concentrations (as measured at the surface), and predicted the development of measurable oxygen concentrations (>0.5 mg/l) earlier than was found experimentally (Figure 4). The model's prediction of lower maximum oxygen may be due to differences between what is modeled versus measured. Specifically, the model represents average concentrations over the photic zone, whereas measured values were taken at a depth where oxygen was likely at its maximum. To determine if it is a discrepancy between what is being measured vs modeled, increased measurement resolution by placing sensors throughout the photic zone would be necessary. The model's tendency to predict measureable oxygen concentration earlier than experimentally observed, especially under low light conditions, may be due to neglecting $\mathrm{O}_{2}$ diffusion from the oxygen productive photic zone deeper into aphotic (anoxic) zone. Furthering this thought concerning the model's late prediction of measurable oxygen concentrations appearing as seen in Figure 4, the flux of oxygen from the photic to aphotic zone early in the experiment is of a similar magnitude to that of oxygen production of 
phytoplankton in the early stages of phytoplankton growth. As phytoplankton populations increase the impact of molecular diffusion on the oxygen concentration decreases relative to other factors such as oxygen production by phytoplankton.

The model only considers aerobic metabolism of bacteria for the removal of $\mathrm{CBOD}_{5}$, and due to the good agreement with experimental results, this appears to be a reasonable simplification. However, when hypoxic conditions prevail, especially under low light conditions with minimal oxygen production by photosynthesis, the model under-predicts the treatment performance (Figure 3). The incorporation of anaerobic processes is likely to improve the robustness and prediction under low light and cold conditions.

Finally, from a practical application, the model was able to capture the influence of organic loading rates and initial carbon concentrations on dissolved oxygen and $\mathrm{CBOD}_{5}$ concentrations (Figures 3 and 4). These are two key parameters that WSP designers are able to control. Such findings suggest arctic WSPs can obtain an effluent concentration for $\mathrm{CBOD}_{5}$ that meet secondary wastewater treatment standards (25 mg/l) with lowered areal loading rates, and more importantly lowered carbon concentrations at the onset of the summer treatment season.

\subsection{Sensitivity Analysis}

A one-factor-at-a-time (OFAT) method local sensitivity analysis (or nominal range analysis) was performed post calibration of the model. An OFAT does not assess the parameter interactions and results of the OFAT may be impacted by the values of other parameters set during the calibration. The sensitivity analysis was carried out on the 20 parameters in Table 1. The parameter range tested was chosen based upon values reported in the literature, listed in Table 4. OFAT is an effective way of determining the model parameters that carry the most influence on output results (Cullen and Frey 1999), and is useful for identifying where to focus data collection related to improving the model (Salehi et al. 2000). These two strengths are directly in-line with the exploratory goals of this paper. In the OFAT, parameters were set to the calibrated value (Table 4) and one parameter at a time was varied over 5 equallyspaced levels that ranged between the high and low values reported in the literature when available (Table 5) or else a range of $(+/-25 \%)$.

Table 5 Parameter values from literature

\begin{tabular}{|c|c|c|c|c|}
\hline Parameter & Definition & Units & Reported Values & Sources \\
\hline
\end{tabular}




\begin{tabular}{|c|c|c|c|c|}
\hline Ihalfsat & $\begin{array}{l}\text { Irradiance half } \\
\text { saturation of } \\
\text { phytoplankton }\end{array}$ & $\frac{\mu \mathrm{E}}{\mathrm{m}^{2}} \mathrm{~s}^{-1}$ & $\begin{array}{c}30 \\
60 \\
220\end{array}$ & $\begin{array}{c}\text { Dauta et al. (1990) } \\
\text { Moreno-Grau et al. (1996) } \\
\text { Beran \& Kargi (2005) }\end{array}$ \\
\hline $\mathrm{K}_{\mathrm{ad}}$ & $\begin{array}{l}\text { Phytoplankton } \\
\text { death rate }\end{array}$ & day $^{-1}$ & $\begin{array}{c}0.05 \\
0.001 \\
0.05-0.25\end{array}$ & $\begin{array}{c}\text { Lawrence \& McCarty } \\
(1970) \\
\text { Moreno-Grau et al. (1996) } \\
\text { Schnoor (1996) }\end{array}$ \\
\hline $\mathrm{K}_{\mathrm{as}}$ & $\begin{array}{c}\text { Phytoplankton } \\
\text { settling/respiration }\end{array}$ & day $^{-1}$ & $\begin{array}{c}0.2 \mathrm{~m} / \mathrm{d} \\
0.05 \\
\end{array}$ & $\begin{array}{c}\text { Schnoor (1996) } \\
\text { Moreno-Grau et al. (1996) } \\
\end{array}$ \\
\hline $\mathrm{K}_{\mathrm{bd}}$ & Bacteria death rate & day $^{-1}$ & $\begin{array}{c}0.035 \\
0.1 \\
0.06 \text { death } \\
0.06-0.015\end{array}$ & $\begin{array}{c}\text { Moreno-Grau et al. (1996) } \\
\text { Buhr \& Miller (1983) } \\
\text { Beran (2005) } \\
\text { Metcalf \& Eddy (2003) }\end{array}$ \\
\hline $\mathrm{K}_{\mathrm{bs}}$ & $\begin{array}{l}\text { Bacteria } \\
\text { respiration/settling } \\
\text { rate }\end{array}$ & day $^{-1}$ & $0.085(+/-25 \%)$ & Moreno-Grau (1996) \\
\hline $\mathrm{K}_{\mathrm{CO} 2}$ & $\begin{array}{l}\text { Half saturation of } \\
\text { phytoplankton on } \\
\text { carbon dioxide }\end{array}$ & $\frac{\mathrm{mg} \mathrm{CO}}{\mathrm{l}}$ & $0.044(+/-25 \%)$ & Buhr \& Miller (1983) \\
\hline $\mathrm{K}_{\mathrm{O} 2}$ & $\begin{array}{l}\text { Half saturation of } \\
\text { bacteria on } \\
\text { oxygen }\end{array}$ & $\frac{\mathrm{mg} \mathrm{O}_{2}}{\mathrm{l}}$ & $\begin{array}{c}0.256 \\
0.128 \\
1\end{array}$ & $\begin{array}{c}\text { Buhr \& Miller 1983 } \\
\text { Banks et al. (2003) } \\
\text { Tchobanoglous et al. } \\
\text { (2003) }\end{array}$ \\
\hline $\mathrm{K}_{\mathrm{p}}$ & $\begin{array}{l}\text { Light abstraction } \\
\text { by phytoplankton }\end{array}$ & $\frac{\mathrm{m}^{-1}}{\mathrm{mg} / \mathrm{l}}$ & $0.138-0.0249$ & $\begin{array}{c}\text { Lorenzen (1972) } \\
\text { Li (2009) } \\
\end{array}$ \\
\hline $\mathrm{K}_{\mathrm{s}}$ & $\begin{array}{l}\text { Half saturation of } \\
\text { bacteria on } \\
\text { substrate }\end{array}$ & $\frac{\mathrm{m}}{\mathrm{day}}$ & $\begin{array}{c}25-100(60) \\
150\end{array}$ & $\begin{array}{l}\text { Metcalf \& Eddy (2003) } \\
\text { Lawrence \& McCarty } \\
\text { (1970) }\end{array}$ \\
\hline $\mathrm{Kl}_{\mathrm{CO} 2}$ & $\begin{array}{l}\text { Carbon Dioxide } \\
\text { transfer rate } \\
\text { (piston velocity) }\end{array}$ & $\frac{\mathrm{m}}{\mathrm{day}}$ & $\begin{array}{c}0.893 \\
1\end{array}$ & $\begin{array}{l}\text { Boogerd et al. (1989) } \\
\text { Schnoor (1996) }\end{array}$ \\
\hline $\mathrm{Kl}_{\mathrm{O} 2}$ & $\begin{array}{l}\text { Oxygen transfer } \\
\text { rate (piston } \\
\text { velocity) }\end{array}$ & $\frac{\mathrm{mg} \mathrm{CBOD}}{\mathrm{l}}$ & $\begin{array}{c}0.15 \\
0.189 \\
0.24\end{array}$ & $\begin{array}{c}\text { Schnoor (1996) } \\
\text { Chu \& Jirka (2003) } \\
\text { Deacon (1977) }\end{array}$ \\
\hline our $_{\mathrm{b}}$ & $\begin{array}{c}\text { Basal oxygen } \\
\text { utilization rate of } \\
\text { bacteria }\end{array}$ & $\frac{\mathrm{mg} \mathrm{O}_{2}}{\mathrm{mg} \mathrm{bac}}$ day $^{-1}$ & $0.15(+/-25 \%)$ & Jenkins (1978) \\
\hline our $_{\mathrm{m}}$ & $\begin{array}{c}\text { Metabolic oxygen } \\
\text { utilization rate of } \\
\text { bacteria }\end{array}$ & $\frac{\mathrm{mg} \mathrm{O}_{2}}{\mathrm{mg} \mathrm{bac}}$ day $^{-1}$ & $0.85(+/-25 \%)$ & Jenkins (1978) \\
\hline $\operatorname{Umax}_{a}$ & $\begin{array}{l}\text { Max growth rate } \\
\text { phytoplankton }\end{array}$ & day $^{-1}$ & $\begin{array}{c}0.3\left(5{ }^{\circ} \mathrm{C}\right) 0.7\left(15^{\circ} \mathrm{C}\right) \\
0.5 \\
0.48\left(5{ }^{\circ} \mathrm{C}\right) 0.78\left(15^{\circ} \mathrm{C}\right) \\
1.13\left(@ 20{ }^{\circ} \mathrm{C}\right) \\
1.5\left(@ 20{ }^{\circ} \mathrm{C}\right)\end{array}$ & $\begin{array}{c}\text { Dauta et al. (1990) } \\
\text { Moreno-Grau et al. (1996) } \\
\text { Buhr \& Miller (1983) } \\
\text { Banks (2003) } \\
\text { Schoor (1996) }\end{array}$ \\
\hline $\operatorname{Umax}_{\mathrm{b}}$ & $\begin{array}{l}\text { Max growth rate } \\
\text { bacteria }\end{array}$ & day $^{-1}$ & $\begin{array}{c}4.95 \\
5.0 \\
2-10\end{array}$ & $\begin{array}{c}\text { Banks (2003) } \\
\text { Moreno-Grau et al. (1996) } \\
\text { Metcalf \& Eddy (2003) }\end{array}$ \\
\hline $\mathrm{Y}_{\mathrm{ca}}$ & $\begin{array}{l}\text { Yield factor of } \\
\text { phytoplankton } \\
\text { produced for } \mathrm{CO}_{2} \\
\text { consumed }\end{array}$ & $\frac{\mathrm{mg} \mathrm{CO}_{2}}{\text { mg Phyplankton }}$ & $\begin{array}{l}2.18 \\
1.83 \\
1.82\end{array}$ & $\begin{array}{c}\text { Fogg (1953) } \\
\text { Cramer \&Myers (1948) } \\
\text { McKinney (2004) }\end{array}$ \\
\hline
\end{tabular}




\begin{tabular}{ccccc}
$\mathrm{Y}_{\mathrm{Ca}} / \mathrm{Y}_{\text {oa }}$ & $\begin{array}{c}\text { Carbon dioxide/ } \\
\text { oxygen produced }\end{array}$ & $\mathrm{mg} \mathrm{CO}_{2} / \mathrm{mg} \mathrm{O}_{2}$ & $1.25-1.37$ & $\begin{array}{c}\text { Fogg (1953) } \\
\text { Cramer \& Myers (1948) } \\
\text { McKinney (2004) }\end{array}$ \\
$\mathrm{BGS}$ & $\begin{array}{c}\text { Bacterial Growth } \\
\text { Self Suppression } \\
\text { Phytoplankton } \\
\text { growth Self } \\
\text { suppression }\end{array}$ & $\mathrm{mg} / \mathrm{l}^{-1}$ & $0.002-0.05$ & Estimated \\
$\mathrm{ED}$ & Unitless & $0.02-0.5$ & Estimated \\
\hline
\end{tabular}

391 Sensitivity coefficients (SC) were developed for two chemical responses, i.e., when dissolved oxygen first exceeds 2

$392 \mathrm{mg} / \mathrm{l}$, and when $\mathrm{CBOD}_{5}$ concentrations are reduced to $30 \mathrm{mg} / \mathrm{l}$ and four biological response metrics, i.e., the timing

393 of and maximum predicted phytoplankton and bacteria populations. The sensitivity coefficient provides a non-

394 dimensional measure of relative influence of parameters to the relative change in the response (Downing et al.

395 1985). The sensitivity coefficient was calculated according to Equation 3.1, and five parameter values (the original

396 and two higher and two lower) were used to determine an average SC over the parameter range (equation 3.2). The

397 SC was taken to be the average to smooth out non-linearities within the relationship. Sensitivity analysis was

398 performed at both lighting and temperature conditions at an initial carbon concentration of $240 \mathrm{mg} / \mathrm{l}$ and $0.0125 \mathrm{l} / \mathrm{d}$

399 loading rate to examine if the sensitivity of the parameters varied with environmental conditions. Tables 6 and 7 list

400 the sensitivity coefficients for timing of dissolved oxygen concentration exceeding $2 \mathrm{mg} / \mathrm{l}$ and timing of $\mathrm{CBOD}_{5}$

401 concentration below $30 \mathrm{mg} / \mathrm{l}$. Insights from Table 5 and 6 will be discussed further in this section.

$$
S C(P)_{i}=\left|\frac{d R}{d P_{i}}\right|_{P^{0}}=\frac{\frac{\frac{R_{i}-R_{O}}{R_{o}}}{P_{i}-P_{o}}}{P_{o}}(3.1)
$$

Where:

$404 \mathrm{R}=$ response vector, $\mathrm{P}=$ parameter vector, $\mathrm{SC}(\mathrm{P})=$ Sensitivity Coefficient of parameter $\mathrm{p}$, and $\mathrm{O}=$ 405 origin of parameter value (middle value of range tested)

$$
S C(P)=\frac{\sum_{i}^{n} S C(P)_{i}}{n}(3.2)
$$

\begin{tabular}{ccccc}
\hline Temperature $\left({ }^{\circ} \mathrm{C}\right)$ & 5 & 15 & 5 & 15 \\
Light $\left(\mu \mathrm{HE} / \mathrm{m}^{2} / \mathrm{s}\right)$ & 250 & 250 & 1000 & 1000 \\
\hline Ihalfsat & 0.41 & 0.47 & 0.49 & 0.67
\end{tabular}


410

\begin{tabular}{ccccc}
$\mathrm{K}_{\mathrm{ad}}$ & $\mathbf{0 . 5 4}$ & $\mathbf{0 . 3 8}$ & $\mathbf{0 . 7 7}$ & $\mathbf{0 . 4 5}$ \\
$\mathrm{K}_{\mathrm{as}}$ & $\mathbf{0 . 1 1}$ & $\mathbf{0 . 1 4}$ & $\mathbf{0 . 1 6}$ & $\mathbf{0 . 1 3}$ \\
$\mathrm{K}_{\mathrm{bs}}$ & 0.03 & 0.01 & 0.02 & 0.01 \\
$\mathrm{~K}_{\mathrm{bd}}$ & $\mathbf{0 . 7 0}$ & $\mathbf{0 . 1 7}$ & $\mathbf{0 . 3 1}$ & 0.03 \\
$\mathrm{~K}_{\mathrm{s}}$ & 0.02 & $\mathbf{0 . 1 0}$ & 0.06 & $\mathbf{0 . 1 7}$ \\
$\mathrm{K}_{\mathrm{O} 2}$ & 0.00 & 0.04 & 0.02 & 0.09 \\
$\mathrm{~K}_{\mathrm{C}}$ & 0.00 & 0.01 & 0.00 & 0.01 \\
$\mathrm{~K}_{\mathrm{p}}$ & 0.03 & $\mathbf{0 . 1 0}$ & 0.02 & 0.04 \\
$\mathrm{Kl}_{\mathrm{CO} 2}$ & 0.00 & 0.00 & 0.00 & 0.00 \\
$\mathrm{Kl}_{\mathrm{O} 2}$ & $\mathbf{0 . 7 3}$ & $\mathbf{0 . 2 6}$ & $\mathbf{0 . 4 7}$ & $\mathbf{0 . 1 4}$ \\
our $_{\mathrm{b}}$ & 0.01 & 0.08 & 0.04 & $\mathbf{0 . 1 5}$ \\
our $_{\mathrm{m}}$ & 0.03 & 0.05 & 0.01 & $\mathbf{0 . 1 9}$ \\
Umax $_{\mathrm{a}}$ & $\mathbf{0 . 9 8}$ & $\mathbf{1 . 4 6}$ & $\mathbf{1 . 3 2}$ & $\mathbf{1 . 7 4}$ \\
Umax $_{\mathrm{b}}$ & 0.03 & 0.01 & 0.02 & 0.01 \\
Yca & $\mathbf{0 . 5 5}$ & $\mathbf{0 . 6 6}$ & $\mathbf{0 . 6 5}$ & $\mathbf{0 . 6 1}$ \\
YcaOYca & $\mathbf{0 . 5 6}$ & $\mathbf{0 . 6 8}$ & $\mathbf{0 . 6 6}$ & $\mathbf{0 . 6 8}$ \\
BGS $_{\text {AGS }}$ & $\mathbf{0 . 8 2}$ & $\mathbf{1 . 5 0}$ & $\mathbf{1 . 4 5}$ & $\mathbf{2 . 6 0}$ \\
ED & $\mathbf{0 . 3 4}$ & $\mathbf{0 . 3 3}$ & $\mathbf{0 . 4 0}$ & $\mathbf{0 . 2 1}$ \\
& $\mathbf{0 . 1 5}$ & $\mathbf{0 . 5 7}$ & $\mathbf{0 . 3 7}$ & $\mathbf{0 . 7 4}$ \\
\hline
\end{tabular}

411

412

Table 7. Parameter sensitivity coefficients for timing of CBOD5 concentration below $30 \mathrm{mg} / \mathrm{l}$

\begin{tabular}{|c|c|c|c|c|}
\hline $\begin{array}{c}\text { Temperature }\left({ }^{\circ} \mathrm{C}\right) \\
\text { Light }\left(\mu \mathrm{E} / \mathrm{m}^{2} / \mathrm{s}\right)\end{array}$ & $\begin{array}{c}5 \\
250\end{array}$ & $\begin{array}{c}15 \\
250\end{array}$ & $\begin{array}{c}5 \\
1000\end{array}$ & $\begin{array}{c}15 \\
1000\end{array}$ \\
\hline Ihalfsat & 0.29 & 0.86 & 0.46 & 0.47 \\
\hline $\mathrm{K}_{\mathrm{ad}}$ & 0.48 & 0.31 & 0.54 & 0.25 \\
\hline $\mathrm{K}_{\mathrm{as}}$ & 0.10 & 0.09 & 0.11 & 0.04 \\
\hline $\mathrm{K}_{\mathrm{bs}}$ & 0.02 & 0.00 & 0.01 & 0.01 \\
\hline $\mathrm{K}_{\mathrm{bd}}$ & 0.73 & 0.26 & 0.36 & 0.20 \\
\hline $\mathrm{K}_{\mathrm{s}}$ & 0.00 & 0.03 & 0.01 & 0.15 \\
\hline $\mathrm{K}_{\mathrm{O} 2}$ & 0.01 & 0.02 & 0.01 & 0.03 \\
\hline $\mathrm{K}_{\mathrm{CO} 2}$ & 0.00 & 0.01 & 0.00 & 0.01 \\
\hline $\mathrm{K}_{\mathrm{p}}$ & 0.03 & 0.06 & 0.02 & 0.01 \\
\hline $\mathrm{Kl}_{\mathrm{CO} 2}$ & 0.00 & 0.00 & 0.00 & 0.00 \\
\hline $\mathrm{Kl}_{\mathrm{O} 2}$ & 0.71 & 0.26 & 0.47 & 0.13 \\
\hline our $_{\mathrm{b}}$ & 0.13 & 0.03 & 0.05 & 0.10 \\
\hline our $_{\mathrm{m}}$ & 0.04 & 0.02 & 0.03 & 0.11 \\
\hline $\mathrm{Umax}_{\mathrm{a}}$ & 0.88 & 1.10 & 1.18 & 0.85 \\
\hline $\operatorname{Umax}_{\mathrm{b}}$ & 0.03 & 0.00 & 0.01 & 0.02 \\
\hline
\end{tabular}




\begin{tabular}{ccccc} 
Yca & $\mathbf{0 . 5 0}$ & $\mathbf{0 . 5 7}$ & $\mathbf{0 . 6 0}$ & $\mathbf{0 . 4 1}$ \\
YcaOYca & $\mathbf{0 . 5 1}$ & $\mathbf{0 . 5 8}$ & $\mathbf{0 . 5 9}$ & $\mathbf{0 . 4 3}$ \\
BGS & $\mathbf{0 . 2 3}$ & $\mathbf{0 . 6 8}$ & 0.03 & $\mathbf{0 . 9 1}$ \\
AGS & $\mathbf{0 . 2 9}$ & $\mathbf{0 . 2 8}$ & $\mathbf{0 . 4 1}$ & $\mathbf{0 . 3 4}$ \\
ED & $\mathbf{0 . 1 2}$ & $\mathbf{0 . 3 9}$ & $\mathbf{0 . 2 7}$ & $\mathbf{0 . 3 2}$ \\
\hline
\end{tabular}

414 A cumulative sensitivity report was constructed to provide a qualitative assessment of parameter sensitivity across

415 the range of temperature and irradiance conditions, and a measure of relative parameter sensitivity in the model.

416 Table 7 provides a sensitivity index by tallying the number of sensitivity coefficients of the 6 tested responses that

417 exceeded 0.1 (a value that was arbitrarily assigned as being an indicator of a sensitive parameter) for a parameter

418 under the noted temperature and irradiance conditions. To provide a comparison of parameter sensitivity, the right

419 column total is a summation of exceedances for a parameter under all temperature/light conditions, and sensitivity

420 ranking of the parameters developed by blending the response sensitivity coefficients. Finally, to compare

421 sensitivity of the model under the four light/temperature pairings, a summation of the sensitivity index for each

422 pairing is provided in the bottom row of Table 7.

423 Table 8 Cumulative sensitivity index by parameter or temperature/irradiance. Value denotes number of SI indices greater than 4240.1 for 6 tested categories (see Tables 6 and 7).

\begin{tabular}{|c|c|c|c|c|c|c|}
\hline $\begin{array}{r}\text { Temperature }\left({ }^{\circ} \mathrm{C}\right) \\
\text { Irradiance }\left(\mathrm{ue} / \mathrm{m}^{2} / \mathrm{s}\right)\end{array}$ & $\begin{array}{r}5 \\
225\end{array}$ & $\begin{array}{r}15 \\
225\end{array}$ & $\begin{array}{c}5 \\
1025\end{array}$ & $\begin{array}{c}15 \\
1025\end{array}$ & Total & $\begin{array}{l}\text { Sensitivity } \\
\text { Ranking }\end{array}$ \\
\hline Ihalfsat & 4 & 6 & 5 & 5 & 20 & 2 \\
\hline $\mathrm{K}_{\mathrm{ad}}$ & 4 & 5 & 6 & 5 & 20 & 5 \\
\hline Kas & 5 & 3 & 5 & 2 & 15 & 12 \\
\hline Kbs & 2 & 0 & 0 & 0 & 2 & 15 \\
\hline Kbd & 5 & 5 & 5 & 3 & 2 & 9 \\
\hline $\mathrm{K}_{\mathrm{s}}$ & 0 & 1 & 0 & 3 & 4 & 14 \\
\hline $\mathrm{K}_{\mathrm{O} 2}$ & 0 & 0 & 0 & 0 & 0 & 18 \\
\hline $\mathrm{K}_{\mathrm{CO} 2}$ & 0 & 0 & 0 & 0 & 0 & 20 \\
\hline $\mathrm{K}_{\mathrm{p}}$ & 0 & 1 & 0 & 0 & 1 & 16 \\
\hline $\mathrm{Kl}_{\mathrm{CO} 2}$ & 0 & 0 & 0 & 1 & 1 & 19 \\
\hline $\mathrm{Kl}_{\mathrm{O} 2}$ & 4 & 5 & 5 & 4 & 18 & 10 \\
\hline our $_{\mathrm{b}}$ & 3 & 3 & 4 & 3 & 13 & 11 \\
\hline our $_{\mathrm{m}}$ & 1 & 0 & 0 & 4 & 5 & 13 \\
\hline Umaxa & 6 & 5 & 5 & 5 & 21 & 1 \\
\hline Umaxb & 0 & 0 & 0 & 0 & 0 & 17 \\
\hline Yca & 6 & 5 & 5 & 5 & 21 & 4 \\
\hline YсаOYсо & 5 & 5 & 5 & 5 & 20 & 6 \\
\hline
\end{tabular}




\begin{tabular}{rrrrr|rr} 
BGS & 5 & 5 & 5 & 6 & 21 & 3 \\
AGS & 6 & 5 & 5 & 4 & 20 & 8 \\
EDFactor & 4 & 5 & 5 & 5 & 19 & 7 \\
\cline { 2 - 5 } Total & 60 & 59 & 60 & 60 & & \\
\hline
\end{tabular}

426

427

428

Parameter sensitivity was consistent for all the tested irradiance and temperature conditions (Table 7). However, the sensitivity of certain parameters, such as oxygen aeration rate $\left(\mathrm{Kl}_{\mathrm{O} 2}\right)$ and bacterial growth self-suppression (BGS) can vary greatly with changing environmental conditions (Tables 5 and 6). Finally, the analysis highlighted the model's sensitivity to phytoplankton growth parameters as six of the seven most sensitive parameters are related to phytoplankton growth rate or metabolism (Table 7).

Critical assessment of the sensitivity analysis provides insight into model dynamics and limiting processes under different conditions. In general, the tested model was more impacted by changing parameter values at lower temperature, and this result reinforces findings that the $\mathrm{CBOD}_{5}$ removal and oxygen dynamics in the WSP are less stable at lower temperature, as also noted by Ragush et al. (2017). The large increase in the sensitivity coefficient of $\mathrm{Kl}_{\mathrm{O} 2}$ at low temperature identifies $\mathrm{CBOD}_{5}$ removal at these low temperatures as being rate limited by the lack of oxygen. The observation of the importance of $\mathrm{Kl}_{\mathrm{O} 2}$ at low temperature highlights the lack of impact of phytoplankton at a temperature of $5{ }^{\circ} \mathrm{C}$, as well as illustrates the importance of phytoplankton in a system intended to remove $\mathrm{CBOD}_{5}$. The BGS parameter, the bacterial carrying capacity, was more sensitive at an increased temperature of $15{ }^{\circ} \mathrm{C}$ compared to $5{ }^{\circ} \mathrm{C}$. This would suggest that once the limitation of oxygen has been removed in WSPs, it is the activity (and size) of the bacterial community that will be the limiter of the $\mathrm{CBOD}_{5}$ treatment rate.

\section{Conclusion}

Our model successfully linked aspects of ecosystem models (phytoplankton growth, irradiance) with wastewater treatment models (bacterial growth, $\mathrm{CBOD}_{5}$ ) though the stoichiometry of reactions utilizing carbon dioxide and oxygen to create a model of arctic WSPs. Our efforts to model WSPs in the arctic shed light on the unique aspect of modeling phytoplankton under poorly mixed conditions, and we demonstrated, that in a poorly mixed system, approaching phytoplankton growth functions through a paradigm of growth optimization is a viable path to developing functions that are representative. A local sensitivity analysis was performed and illustrated the 
importance of phytoplankton for the removal of $\mathrm{CBOD}_{5}$ and the development of facultative conditions (> 2 mg/l DO).

Our box model of the photic zone of WSPs operating under arctic conditions had the ability to predict the trends in $\mathrm{CBOD}_{5}$ and DO concentrations presented in Ragush et al. (2017) for different light and irradiance conditions. Highlighted in the study, is that the difference in the phytoplankton growth rate was largely responsible for WSP treatment performance in the temperature range of $5-15^{\circ} \mathrm{C}$. The $\mathrm{CBOD}_{5}$ removal rate was oxygen limited in instances when phytoplankton concentrations were small, and point to the requirement of either supporting the phytoplankton population's growth under these cold conditions or supplementing oxygen in WSPs with aeration to achieve effective $\mathrm{CBOD}_{5}$ treatment. In terms of supporting the phytoplankton population's growth, the most logical method is increasing the temperature in these systems, and the most intuitive way of potentially doing so is providing shallow summer treatment cells (less than $1.5 \mathrm{~m}$ deep).

\section{Acknowledgements}

The authors would like to thank the Government of Nunavut and the Natural Science and Engineering Research Council of Canada for their financial support of this research.

\section{References}

Banks, C. J., Koloskov, G. B., Lock, A. C., \& Heaven, S. (2003). A computer simlulation of the oxygen balance in a cold climate winter storage WSP during the critical spring warm-up period. Water Science and Technology, 48(2), 189-195.

Behrenfeld, M. J., \& Falkowski, P. g. (1997). A consumer's guide to phytoplankton primary productivity models. Limnology and Oceanography, 42(7), 1479-1491. doi:10.4319/lo.1997.42.7.1479

Benson, B. B., \& Krause, D. J. (1984). The concentration and isotopic fractionation of oxygen dissolved in freshwater and seawater in equilibrium with atmosphere. Limnology and Oceography, 29(3), 620-632. doi:10.4319/lo.1984.29.3.0620

Beran, B., \& Kargi, F. (2005). A dynamic mathmatical model for wastewater stabilization ponds. Ecological Modelling, 181(1), 39-57. doi:10.1016/j.ecolmodel.2004.06.022 
Boogerd, F., Bos, P., Kuenen, J., Heijnen, J., \& van der Lans, R. (1990). Oxygen and carbon dioxide mass transfer and the aerobic, autotrophic cultivation of moderate and extreme thermophiles: a case study relate to microbial desulfurization of coal. Biotechnology and Bioengineering, 35(11), 1111-1119.

Boyd, C. E. (1973). The chemical oxygen demand of waters and biological materials from ponds. Transactions of the American Fisherieis Society, 102(3), 606-611.

Buhr, H., \& Miller, S. (1983). A dynamic model of the high-rate algal-bacterial wastewater treatment pond. Water Research, 17(1), 29-37. doi:10.1016/0043-1354(83)90283-X

Chu, C. R., \& Jirka, G. H. (2003). Wind and stream flow induced reaeration. Journal of Environmental Engineering, 129(12), 1129-1136. doi:10.1061/(ASCE)0733-9372(2003)129:12(1129)

Contois, D. (1959). Kinetics of bacterial growth:relationship between oopulation density and specific growthrate of continuous cultures. Journal of General Microbiology, 21, 40-50.

Cramer, M., \& Myers, J. (198). Nitrate reduction and assimilation in Chlorella pyrenoidsa. Joural of Genral Physiology, 93-102.

Cullen, A., \& Frey, H. (1999). Probabilistic Techniques in Exposure Assessment. A handbook for dealing with Variability and Uncertainty in Models and Inputs. New York and London: Plenum Press.

Dauta, A., Devau, J., Piquemal, F., \& Boumnich, L. (1990). Growth rate of four freshwater algae in relation to light and temperature. Hydrobiologia, 207(1), 221-226. doi:10.1007/BF00041459

Dawson, R. N., \& Grainge, J. (1969). Design criteria for wastewater lagoons in arctic and sub-arctic regions. Water Pollution Control Federation, 41(2), 237-246.

Deacon, E. (1977). Gas transfer to and across an air-water interface. Tellus, 363-374.

Downing, D. J., Gardner, R. H., \& Hoffman, F. O. (1985). An examination of response-surface methodologies for uncertainty analysis in assessment models. Technometrics, 27(2), 151-163. doi:10.2307/1268763

Elmore, H., \& West, W. (1961). Effect of water temperature on stream reaeration. Joural of Sanitization Engineering Divistion - American Society of Civil Engineers(87), 59-71. 
497

498

499

500

501

502

503

504

505

506

507

508

509

510

511

512

513

514

515

516

517

518

519

Fogg, G. E. (1953). The Metabolism of Algae. New York: John Wiley \& Sons.

Fritz, J. J., Middleton, A. C., \& Meredith, D. D. (1979). Dynamic process modeling of wastewater stabilization ponds. Journal of the Water Pollution Control Federation, 51(11), 2724-2743.

Gaudy Jr., A., Bhalta, M., \& Gaudy, E. (1964). Use of chemical oxygen demandvalues of bacterial cells in wastewater purification. Applied Microbiology, 12(3), 254-260.

Government of Canada. (2012, June 29). Justice laws website. Retrieved from Government of Canada: http://awslois.justice.gc.ca/eng/regulations/SOR-2012-139/FullText.html

Heinke, G., Smith, D., \& Finch, G. (1991). Guidelines for planning and design of wastewater lagoon systems in cold climates. Canadian Journal of Civil Engineering, 18(4), 556-566.

Henze, M. (1979). Sewage Treatment by Activated Sludge - A model with emphasis on oyxgen consumption and sludge composition. Proceedings of a Post-Conference Seminar held at the Technical University of Denmark (pp. 41-60). Oxford: Pergamon Press.

Huisman, J., \& Weissing, F. J. (1994). Light-limited growth and competion for light in well-mixed aquatic enviroments: An elementary model. Ecology, 75(2), 507-520. doi:10.2307/1939554

Klausmeier, C. A., \& Litchman, E. (2001). Algal games: the vertical distribution of phytoplankton in poorly mixed water columns. Limnology and Oceanography, 46(8), 1998-2007. doi:10.4319/lo.2001.46.8.1998

Klemetson, S. (1983). Solar Heating of Wastewater Stabilization Ponds. Fort Collins, Colorado: Colorado State University.

Lawrence, A. W., \& McCarty, P. L. (1970). Unified basis for biological treatment design and operation. Journal of Sanitary Engineering Division, 96(3), 757-778.

Li, Q. P., Franks, P. J., Landry, M. R., Georicke, R., \& Taylor, A. G. (2010). Modeling phytoplankton growth rates and chlorophyll to carbon rations in california coastal and pelagic ecosytems. Journal of Geophysical Research, 115(G4), 1-12. doi:10.1029/2009JG001111 
Long, S. P., \& Humphries, S. (1994). Photoinhibition of photosynthesis innature. Annual Review of Plant Physiology and Plant Molecular Biology, 45, 633-662. doi:10.1146/annurev.pp.45.060194.003221

Lorenzen, C. J. (1972). Extinction of light in the ocean by phytoplankton. ICES Journal of Marine Science, 34(2), 262-267. doi:10.1093/icesjms/34.2.262

McKinney, R. E. (2004). Environmental Pollution Control Microbiology. New York: CRC Press.

Mellard, J. P., Yoshiyama, K., Litchman, E., \& Klausmeier, C. A. (2011). The vertical distribution of phytoplankton in stratisfied water columns. Journal of Theoretical Biology, 269(1), 16-30. doi:10.1016/j/jtbi.2010.09.041

Metcalf \& Eddy. (2003). Wastewater Engineering treatment and reuse: Fourth Edition. New York: McGraw-Hill.

Moreno-Grau, S., Garcia-Sanchez, A., Moreno-Clavel, J., Serrano-aniorte, J., \& Moreno-Grau, M. (1996). A mathematical model for waste water stabilization ponds with macrophytes and microphytes. Ecological Modelling, 91(1-3), 77-103. doi:10.1016/0304-3800(95)00168-9

National Institute of Standards and Techology. (2015, 02 09). Carbon Dioxide. Retrieved from NIST Chemistry WebBook: http://webbook.nist.gov/chemistry/

Nunavut Water Board. (2015, July 10). Public Registry ftp. Retrieved from Nunavut Water Board: http://www.nwboen.ca

Orhon, D., \& Artan, N. (1994). Modelling of Activated Sludge Systems. Lancaster: Technomic Publishing.

Ragush, C. M., Poltarowicz, J. M., Lywood, J., Gagnon, G. A., Truestrup-Hansen, L., \& Jamieson, R. C. (2017). Understanding the Influence of light, temperature and organic loading rates on oxygen dynamics and carbon removal in wastewater stabilization ponds operating in arctic environments. Ecological Engineering, 98, 91-97. doi:10.1016/j.ecoleng.2016.10.03

Ragush, C. M., Schmidt, J. J., Kroksek, W. H., Gagnon, G. A., Truelstrup-Hansen, L., \& Jamieson, R. C. (2015). Performance of municipal waste stabilization ponds in the Canadian Arctic. Ecological Engineering, 83, 413-421. doi:10.1016/j.ecoleng.2015.07.008 
543 Salehi, F., Prasher, S., Amin, S., Madani, A., Jebelli, S., Ramaswamy, H., \& Drury, C. (2000). Prediction of annual 544 nitrate-N losses in drain outflows with artificial neural networks. Transaction of ASAE, 43(5), 1137-1143.

545 Schnoor, J. L. (1996). Environmental Modeling: Fate and Transport of Pollutants in Water, Air and Soil. New $546 \quad$ York: John Wiley \& Sons.

547 Shilton, A. (2005). Pond Treatment Technology. London: IWA.

548 US EPA. (1983). Design Manual: Municipal Wastewater Stabilization Ponds. Environmental Protection Agency.

549 Zweitering, M., Jongenburger, I., Rombouts, F., \& RIET, K. V. (1990). Modeling of bacterial growth curve. Applied 550 and Environmental Microbiology, 56(6), 1875-1881. doi:0099-2240/90/061875-07\$02.00/0

551 